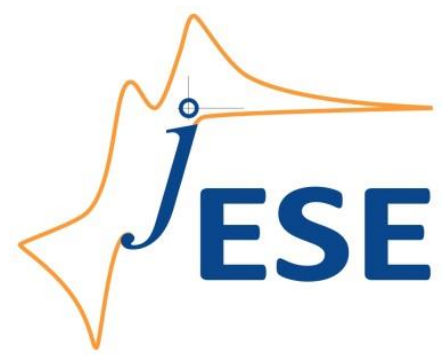

Open Access: ISSN 1847-9286

www.jESE-online.org

Original scientific paper

\title{
A novel vitamin B9 sensor based on modified screen-printed electrode
}

\author{
Maryam Zare and Hamid Sarhadi ${ }^{\square}$ \\ Department of Food Science, Bam Branch, Islamic Azad University, Bam, Iran \\ Corresponding author: ${ }^{\bowtie}$ sarhadihamid2020@gmail.com; Tel.: +98 3444342489; Fax: +98 3444342489
}

Received: June 14, 2020; Revised: July 14, 2020; Accepted: September 16, 2020

\begin{abstract}
In the field of determination of vitamin B9 (folic acid, FA), we have described the development of a sensitive electrochemical sensor through promoting the screen-printed electrode (SPE) and taking the advantage of zinc ferrite magnetic nanoparticles ( $\mathrm{ZnFe}{ }_{2} \mathrm{O}_{4} \mathrm{MNPS}$ ). Cyclic voltammetry (CV) experiments demonstrated the powerful activity of $\mathrm{ZnFe}{ }_{2} \mathrm{O}_{4} \mathrm{MNPS} / \mathrm{SPE}$ for electrooxidation of $\mathrm{FA}$ by showing the prominent oxidation peak at $600 \mathrm{mV}$ vs. Ag/AgCl. By differential pulse voltammetry (DPV) measurements, a linear relation between current response and concentration of vitamin $B 9$ was determined in the range of 1.0-100.0 $\mu \mathrm{M}$, and detection limit is found to be $0.3 \mu \mathrm{M}(\mathrm{S} / \mathrm{N}=3)$. Except high sensitivity, the developed sensor demonstrated high stability, reproducibility and repeatability, and was also successfully applied to specify FA in real samples of vitamin $B 9$ tablets and human urine.
\end{abstract}

\section{Keywords}

Voltammetric sensor; folic acid; modified electrode; $\mathrm{ZnFe}_{2} \mathrm{O}_{4}$ magnetic nanoparticles

\section{Introduction}

Vitamin B9 is folic acid (FA), N-[4-[[(2-amino-4-oxo-1,4-dihydropteridin-6-yl)methyl]amino] benzoyl]-L-glutamic acid, which can be dissolved in water and commonly found in fresh fruits, vegetables, liver, and yolk [1,2]. FA is necessary in many biological functions and is a significant compound in the process of repair of DNA, synthesis and methylation of DNA, and synthesis of red blood cells in human's body [3-5]. The deficiency of FA in human's body can cause many disorders such as higher risk of neural tube defects, hypomethylation, colorectal cancer and, it can induce proto-oncogene expression causing cancer [6-8]. Hence, the specification of FA is considered necessary in pharmaceutical, food, and clinical samples.

Most of literature investigations on determination and quantification of FA are using fluorimetry [9], capillary electrophoresis [10], spectrophotometry [11], flow injection analysis [12], 
high performance liquid chromatography [13] and chemiluminescence analysis [14]. All these techniques are commonly expensive, show low sensitivity, take long time for each testing, and require sample pretreatment by organic solvent extraction. Therefore, using new alternative techniques is supposed to be very useful.

In recent years, electrochemical methods and particularly voltammetry, have attracted significant attention due to their benefits like sensitivity, simplicity, low cost, accuracy and selective specification of electroactive species [15-28]. In addition, the usage of electrochemical approach towards detection of FA is generally promising because FA is the electrochemically active compound $[29,30]$.

Among many potentially useful electrodes, screen-printed electrodes (SPEs) provide many benefits for electrochemical sensors, such as low cost, portability, ease of chemical modification, rapid response, and flexible design [31-36]. For determining the trace level of FA, however, the signal to noise ratio of the bare, i.e. unmodified SPE is not high enough. Therefore, the scientists tried to modify bare SPE surfaces by different sorts of modifiers. Among modifiers, nano-materials can be a good choice due to their high surface-to-volume ratio which will significantly increase the voltammetric response. Also, presence of nanomaterials leads to faster electron transfer between the electrode and analyte [37-48].

In order to construct electrochemical sensors and biosensors, many nanomaterials like metal oxides, metals, semiconductor NPs, and carbon-based materials have already been employed [49-51]. Among them, $\mathrm{ZnFe}_{2} \mathrm{O}_{4}$ magnetic NPs showed promising electronic and magnetic characteristics and thermal stability, which are commonly appropriate to a broad range of usage like drug delivery technology, magnetic resonance imaging (MRI), and gas sensing [52-55].

The main goal of the present work is to take advantages of both SPE and $\mathrm{ZnFe}_{2} \mathrm{O}_{4}$ magnetic NPS and combine them in a sensor for specifying the amounts of vitamin B9 (FA) in various real samples.

\section{Experimental}

\section{Chemicals and apparatus}

Autolab potentiostat/galvanostat (PGSTAT 302N, Eco Chemie, the Netherlands) was utilized for electrochemical measurements. General Purpose Electrochemical System (GPES) software was used for controlling experimental conditions. SPE (DropSens; DRP-110: Spain) possessed three electrodes, i.e. an unmodified graphite working electrode, graphite counter electrode and $\mathrm{Ag} / \mathrm{AgCl}$ reference electrode. Metrohm $710 \mathrm{pH}$ meter was utilized in order to determine $\mathrm{pH}$.

FA and all the remaining reagents were of analytical grade and provided by Merck (Darmstadt, Germany). Orthophosphoric acid and the related salts were utilized to prepare the buffer solutions of $\mathrm{pH}$ in the range of 2.0-9.0. $\mathrm{ZnFe}_{2} \mathrm{O}_{4}$ nanoparticles were synthesized according to the literature [56].

\section{Preparation of real samples}

Drug-free human urine specimens were stored in a refrigerator immediately after collection. Firstly, $10 \mathrm{ml}$ of each sample was used and centrifuged at $2000 \mathrm{rpm}$ for 15 minutes and the supernatant passed through $0.45 \mu \mathrm{m}$ filter. Next, various quantities of the treated urine samples were taken and transferred to a flask and diluted by utilizing a phosphate buffer solution (PBS) with $\mathrm{pH}$ of 7.0. For these samples, various quantities of FA were spiked. The standard addition approach was utilized to determine FA concentrations. 
Five FA tablets labelled as $100 \mathrm{mg}$ per tablet, Tehran Chemie Pharmaceutical Co., Iran) were firstly grounded to a powder. Afterwards, the tablet solution was prepared via dissolving $500 \mathrm{mg}$ of the powder in $25 \mathrm{ml}$ water through ultra-sonication. Various volumes of the diluted solution have been transported to $25 \mathrm{ml}$ volumetric flasks and diluted to the marks with PBS, pH 7.0. FA contents were analysed by the recommended technique via the standard addition method.

\section{Results and discussion}

\section{Electrochemical profile of FA at $\mathrm{ZnFe}_{2} \mathrm{O}_{4} M N P S / S P E$}

The mechanism of FA oxidation is schematically drawn in Figure 1 where electrochemical oxidation of FA has been proposed as $2 \mathrm{e}^{-} / 2 \mathrm{H}^{+}$reaction, what suggests $\mathrm{pH}$ dependent electrochemical response [57]. Therefore, finding of the optimum $\mathrm{pH}$ value would be required for achieving precise outputs. The modified electrodes were tested at $\mathrm{pH}$ values ranging between 2.0 and 9.0. The most acceptable output for FA electrooxidation was observed at $\mathrm{pH}$ 7.0.<smiles>C[C+]([I+])c1ccc(N=Cc2cnc3nc(N)ncc3n2)cc1C(=O)NC(CCC(=O)O)C(=O)O</smiles>

Figure 1. Electrochemical mechanism for oxidation of folic acid [57].

Figure 2 represents cyclic voltammograms (CV) of bare SPE (curve a) and $\mathrm{ZnFe}_{2} \mathrm{O}_{4} \mathrm{MNPs}_{\text {modified }}$ SPE (curve b) in $0.1 \mathrm{M}$ PBS ( $\mathrm{pH}$ 7.0) containing $60.0 \mu \mathrm{M}$ of FA. Based on CV outcomes, it may be stated that much higher oxidation peak current of $\mathrm{FA}$ was recorded for $\mathrm{ZnFe}_{2} \mathrm{O}_{4} \mathrm{MNPs} / \mathrm{SPE}$, proving thus higher sensitivity of modified electrode than bare SPE. Also, peak potential for modified SPE occurred at $590 \mathrm{mV}$, what is about $70 \mathrm{mV}$ more negative in comparison to the unmodified SPE. This suggests that modifying SPE with $\mathrm{ZnFe}_{2} \mathrm{O}_{4}$ MNPs improved the catalytic activity of the electrode towards FA. 


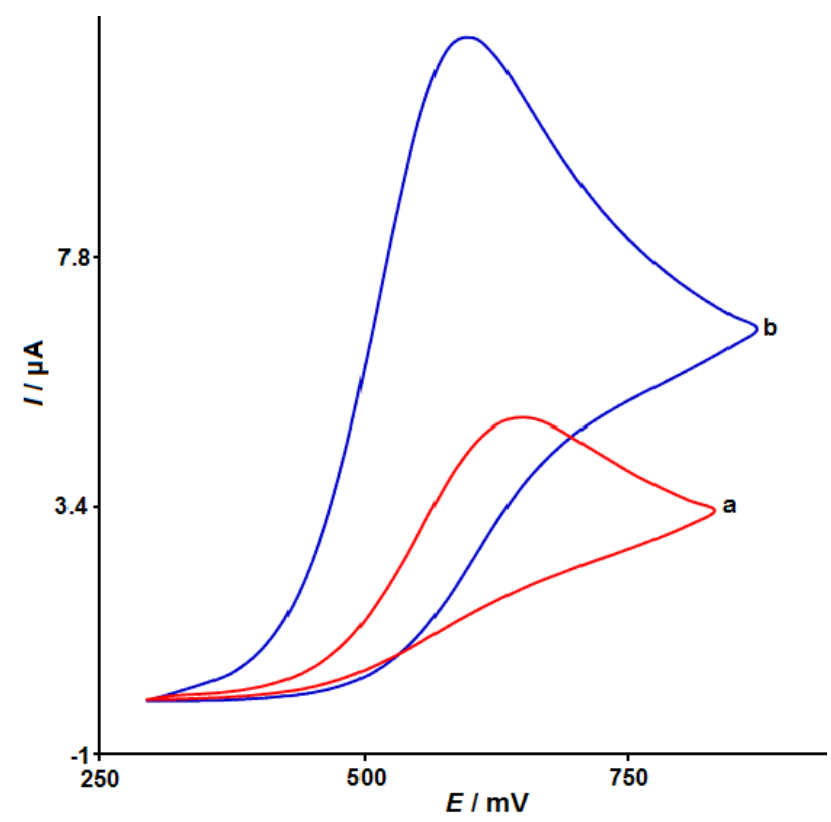

Figure 2. $\mathrm{CVs}\left(50 \mathrm{mV} \mathrm{s}^{-1}\right)$ of a) SPE and b) $\mathrm{ZnFe}_{2} \mathrm{O}_{4} \mathrm{MNPS} / \mathrm{SPE}$ in presence of $60.0 \mu \mathrm{M}$ of FA in $0.1 \mathrm{M} P B S(p H$ 7.0).

\section{Effect of scan rate}

Figure 3 presents the effect of potential scan rate changes on the oxidation currents of vitamin B9 (FA), recorded by linear sweep voltammetry (LSV). The results show increase of anodic currents with potential scan rate, and only minor shifts of peak potential values. It can be observed in the inset of Figure 3 that the peak current $\left(I_{p}\right)$ and the square root of the potential scan rate $\left(v^{1 / 2}\right)$ are linearly associated, what demonstrates that the oxidation process of FA is fast and almost diffusioncontrolled process.

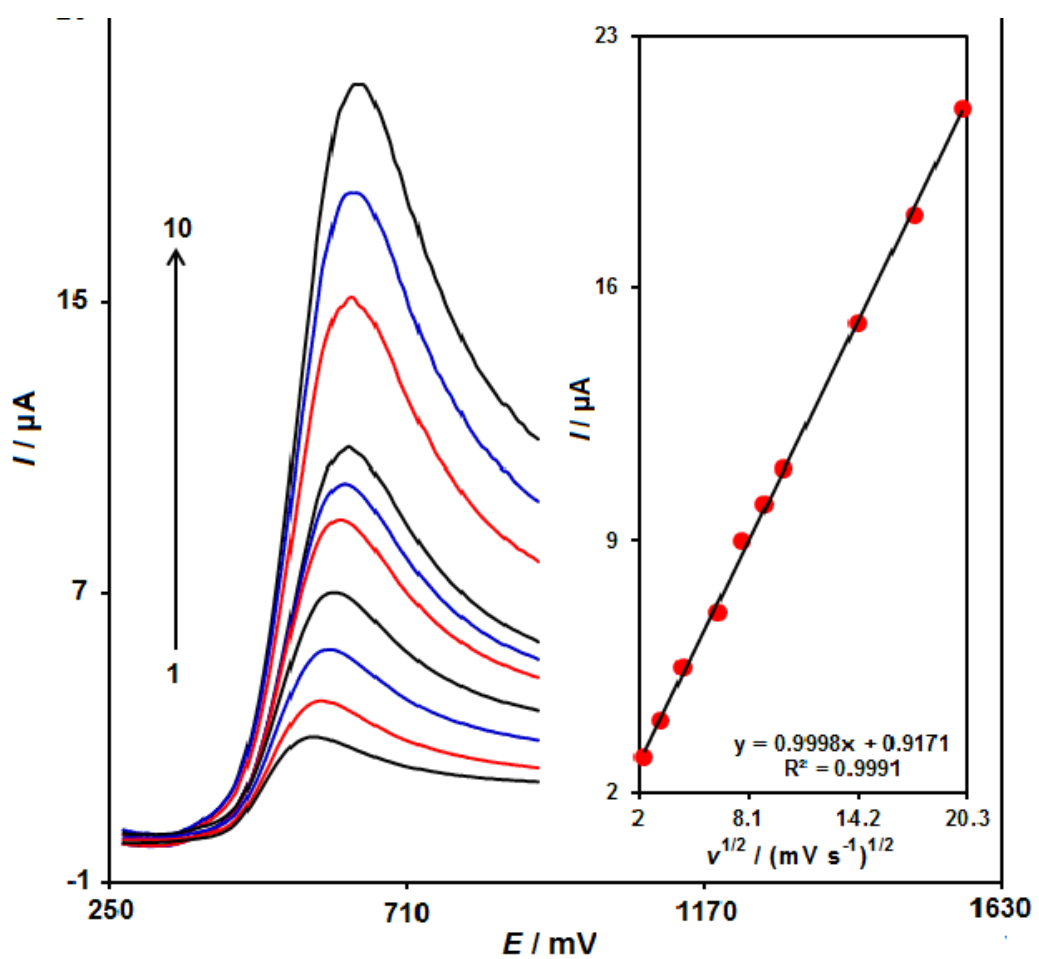

Figure 3. LSVs of $\mathrm{ZnFe}_{2} \mathrm{O}_{4} \mathrm{MNPS} / \mathrm{SPE}$ in $0.1 \mathrm{M} \mathrm{PBS}(\mathrm{pH}$ 7.0) containing 40.0 $\mu \mathrm{M}$ FA at different scan rates (1-10 correspond to $v=5,10,20,40,60,80,100,200,300$ and $\left.400 \mathrm{mV} \mathrm{s}^{-1}\right)$. Inset: variation of anodic peak current vs. $v^{1 / 2}$. 


\section{Chronoamperometric analysis}

For chronoamperometric analysis, the working electrode potential was set at $0.64 \mathrm{~V}$ for each sample solution containing different concentration of vitamin B9 in $0.1 \mathrm{M} \mathrm{PBS} \mathrm{(pH} \mathrm{7.0),} \mathrm{and} \mathrm{the}$ outputs are shown in Figure 4. Generally, the current for an electroactive material such as vitamin $\mathrm{B} 9$ at the mass transport limited condition, could be illustrated by Cottrell's equation:

$$
I=n F A D^{1 / 2} C_{b} \pi^{-1 / 2} t^{-1 / 2}
$$

In eq. (1), $n, C_{b}, D$ and $A$ refer to the number of electrons in redox reaction, bulk concentration of analyte $(\mathrm{mol} \mathrm{cm})$, diffusion coefficient $\left(\mathrm{cm}^{2} \mathrm{~s}^{-1}\right)$ and surface area of the electrode $\left(\mathrm{cm}^{2}\right)$, respectively. The optimized fitting results of $/$ vs. $t^{-1 / 2}$ linear plots based on the experiments are, for different vitamin B9 samples, presented in Figure 4A. The slopes of the obtained straight lines vs. concentration of vitamin $\mathrm{B} 9$ are shown in Figure $4 \mathrm{~B}$.

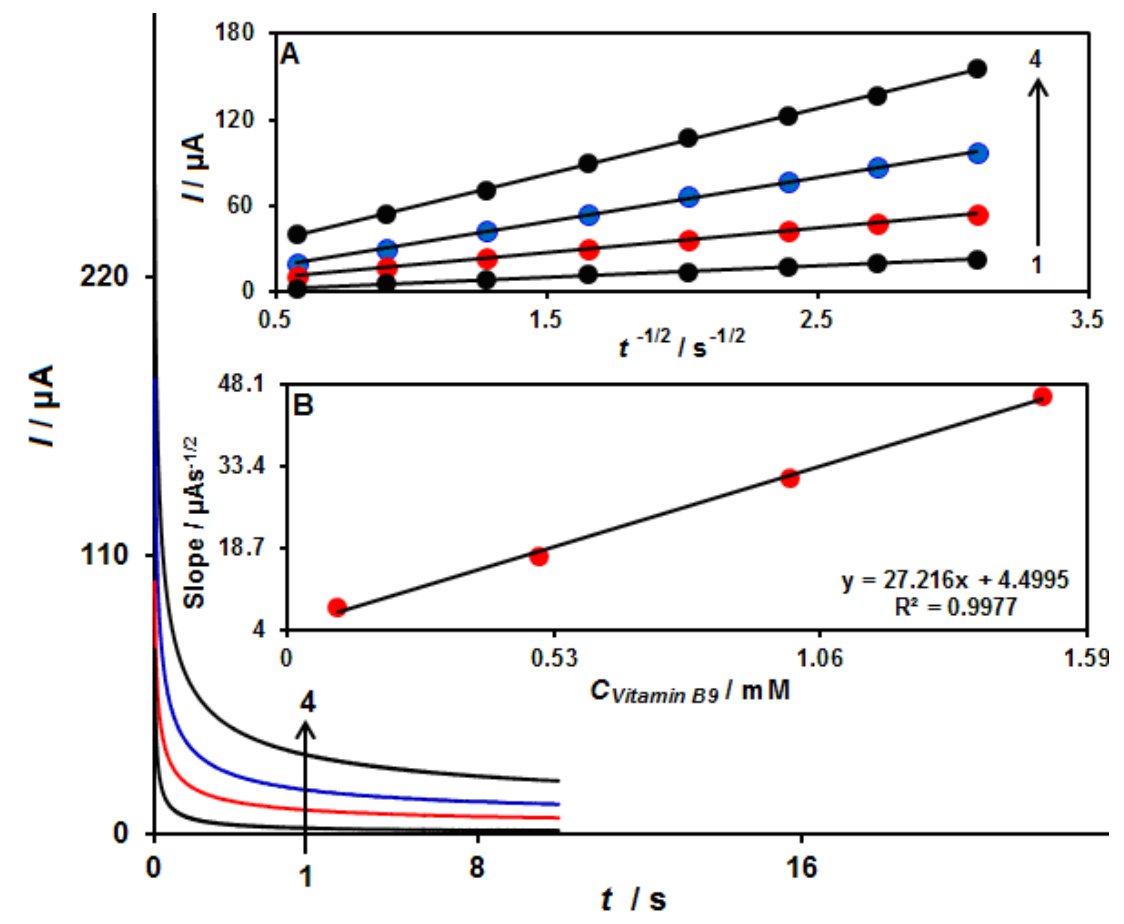

Figure 4. Chronoamperograms of $\mathrm{ZnFe}_{2} \mathrm{O}_{4} \mathrm{MNPS} / \mathrm{SPE}$ in $0.1 \mathrm{M} P B S(p H$ 7.0) for various concentrations of vitamin $B 9$ (1 to 4 correspond to $0.1,0.5,1.0$, and $1.5 \mathrm{mM}$ of FA). Inset (A): current vs. $t^{-1 / 2}$ plots achieved from chronoamperograms 1 to 4 . Inset

(B): slopes of straight lines in Fig. $4 B$ vs. vitamin $B 9$ concentrations.

Considering Cottrell equation (1), the resulting slopes in Figure 4, $n=2$ (Figure 1), and geometric surface area of WE of $0.0341 \mathrm{~cm}^{2}, D$ value for FA in PBS solution was calculated equal to $6.3 \times 10^{-5} \mathrm{~cm}^{2}$ $\mathrm{s}^{-1}$.

\section{Calibration plot and limit of detection}

Vitamin B9 (FA) was quantitatively analyzed using differential pulse voltammetry (DPV), because DPV technique offers several benefits, like better sensitivity for the analytical utilization. DPVs of the modified electrode $\left(\mathrm{ZnFe}_{2} \mathrm{O}_{4} \mathrm{MNPs} / \mathrm{SPE}\right.$ ) for different concentrations of vitamin $\mathrm{B} 9$ (1.0 to 100.0 $\mu \mathrm{M})$ in $0.1 \mathrm{M}$ PBS ( $\mathrm{pH} 7.0$ ) are shown in Figure 5. It is obvious from the inset of Figure 5 that the oxidation peak current and concentration of vitamin $\mathrm{B} 9$ are linearly correlated in the concentration range between 1.0 to $100.0 \mu \mathrm{M}$, with the correlation coefficient 0.9994 . Limit of detection (LOD) is found equal to $0.3 \mu \mathrm{M}$. 


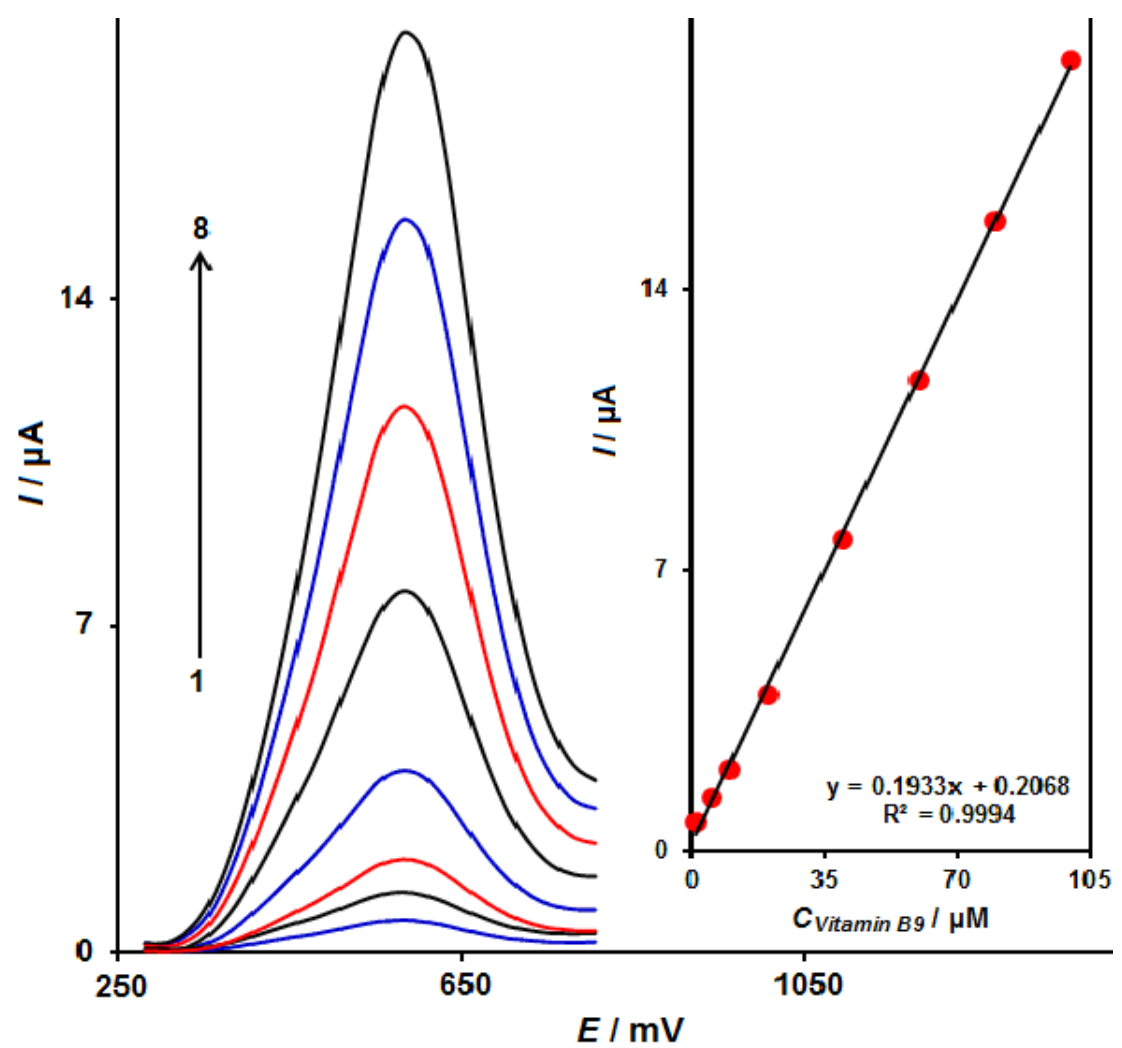

Figure 5. DPVs of $\mathrm{ZnFe}_{2} \mathrm{O}_{4} \mathrm{MNPS} / \mathrm{SPE}$ in $0.1 \mathrm{MPBS}(\mathrm{pH}$ 7.0) containing diverse concentrations of vitamin B9 (1 to 8 correspond to 1.0, 5.0, 10.0, 20.0, 40.0, 60.0, 80.0 and 100.0 $\mu \mathrm{M}$ ) Inset: peak current plot vs. vitamin $B 9$ concentrations from 1.0-100.0 $\mu \mathrm{M}$.

\section{Stability and repeatability of $\mathrm{ZnFe}_{2} \mathrm{O}_{4} M N P S / S P E$}

Stability of $\mathrm{ZnFe}_{2} \mathrm{O}_{4} \mathrm{MNPS} / \mathrm{SPE}$ was tested by maintaining the proposed sensor electrode for 15 days in PBS solution of $\mathrm{pH}$ 7.0. Prior and after immersion, cyclic voltammograms were recorded in the solution containing $30.0 \mu \mathrm{M}$ of FA to obtain information on the stability of the prepared sensor electrode. A slight decrease in voltammetric response equal to $2.1 \%$ was observed comparing with the initial response. This confirms that $\mathrm{ZnFe}_{2} \mathrm{O}_{4} \mathrm{MNPS} / \mathrm{SPE}$ is highly stable sensor electrode.

The anti-fouling characteristic for the oxidation of FA were tested by cyclic voltammetry of the modified SPE before and after its use in the presence of FA. Cyclic voltammograms were recorded after 15 potential cycles performed at $50 \mathrm{mV} \mathrm{s}^{-1}$ in the presence of FA. It was found that the current values were reduced less than $2.3 \%$, while the peak potential is not changed. These experimental results approved high electrode repeatability.

\section{Analysis of real samples}

For assessing the usefulness of here proposed $\mathrm{ZnFe}_{2} \mathrm{O}_{4}$ MNPs/SPE sensor for FA determination, the analyses in some real samples were performed. Quantifications of FA in vitamin B9 tablets and human urine samples were performed using the standard addition method, and the obtained analytical results are presented in Table 1. It must be added here that the recovery of FA was found satisfactory, as well as reproducibility which was demonstrated on the basis of mean relative standard deviation (RSD) (1.7-3.5). 
Table 1. Analytical results of $\mathrm{ZnFe}_{2} \mathrm{O}_{4} \mathrm{MNPS} / \mathrm{SPE}$ for determination of FA in vitamin B9 tablet and urine samples $(n=5)$.

\begin{tabular}{|c|c|c|c|c|}
\hline \multirow{2}{*}{ Sample } & \multicolumn{2}{|c|}{ Concentrations, $\mu \mathrm{M}$} & \multirow{2}{*}{ Recovery, \% } & \multirow{2}{*}{ RSD, \% } \\
\cline { 2 - 5 } & Spiked & Found & & 2.9 \\
\hline \multirow{3}{*}{ Vitamin B9 tablet } & 0 & 6.0 & - & 3.4 \\
\cline { 2 - 5 } & 2.5 & 8.6 & 101.2 & 1.8 \\
\cline { 2 - 5 } & 5.0 & 10.8 & 98.2 & 2.2 \\
\cline { 2 - 5 } & 7.5 & 14.0 & 103.7 & 3.0 \\
\cline { 2 - 5 } & 10.0 & 15.9 & 99.4 & - \\
\hline \multirow{3}{*}{ Urine } & 0 & - & - & 1.7 \\
\cline { 2 - 5 } & 5.0 & 4.9 & 103.0 & 2.2 \\
\cline { 2 - 5 } & 10.0 & 10.3 & 101.3 & 3.5 \\
\cline { 2 - 5 } & 15.0 & 15.2 & 99.0 & 2.6 \\
\cline { 2 - 5 } & 20.0 & 19.8 & 103.0 & - \\
\hline
\end{tabular}

\section{Conclusions}

A disposable electrochemical sensor for detection of vitamin B9 (folic acid, FA) was developed using a screen-printed electrode (SPE) modified by $\mathrm{ZnFe}_{2} \mathrm{O}_{4}$ magnetic nanoparticles (NPs). Based on the advantages of SPE technology in combination with excellent electrocatalytic properties of magnetic $\mathrm{ZnFe}_{2} \mathrm{O}_{4} \mathrm{NPs}$, a highly suitable sensor for FA was developed. Modified SPE showed significantly improved oxidation peak current in comparison with unmodified SPE. The electrochemical efficiency of the modified sensor was assessed using DPV, showing a wide linear range (1.0-100.0 $\mu \mathrm{M})$ and low detection limit of $0.3 \mu \mathrm{M} F A$. Testing performed with the developed $\mathrm{ZnFe}_{2} \mathrm{O}_{4} \mathrm{MNPs} / \mathrm{SPE}$ showed appropriate sensitivity, reproducibility, stability and repeatability of sensor electrode for exact determination of FA. Determination of vitamin B9 in some real samples (vitamin B9 pharmaceutical tablets and human urine) performed using the developed sensor and standard addition method, showed very acceptable results.

\section{References}

[1] X. Li, X. Tan, J. Yan, Q. Hu, J. Wu, H. Zhang, X. Chen, Electrochimica Acta 187 (2016) 433-441 https://doi.org/10.1016/i.electacta.2015.11.082.

[2] M. Venu, V. K. G. S. Agarwa, S. Venkateswarlu, G. Madhavi, International Journal of Electrochemical Science 13 (2018) 11702-11719 https://doi.org/10.20964/2018.12.41.

[3] M. P. Kingsley, P. B. Desai, A. K. Srivastava, Journal of Electroanalytical Chemistry 741 (2015) 71-79 https://doi.org/10.1016/i.jelechem.2014.12.039.

[4] L. He, Q. Wang, D. Mandler, M. Li, R. Boukherroub, S. Szunerits, Biosensors and Bioelectronics 75 (2016) 389-395 https://doi.org/10.1016/j.bios.2015.08.060.

[5] X. L. Jiang, R. Li, J. Li, X. He, Russian Journal of Electrochemistry 45 (2009) 772-777 https://doi.org/10.1134/S1023193509070106.

[6] H. Mahmoudi Moghaddam, H. Beitollahi, S. Tajik, H. Soltani, Electroanalysis 27 (2015) 2620-2628 https://doi.org/10.1002/elan.201500166.

[7] D. Sangamithirai, S. Munusamy, V. Narayanan, A. Stephen, Materials Science and Engineering: C 91 (2018) 512-523 https://doi.org/10.1016/i.msec.2018.05.070.

[8] F. C. Chiang, C. C. Chang, S. M. Chen, T. W. Chen, M. Govindasamy, H. J. Yang, International Journal of Electrochemical Science 13 (2018) 4613-4624 https://doi.org/10.20964/2018.05.71.

[9] P. Anastasopoulos, T. Mellos, M. Spinou, T. Tsiaka, M. Timotheou-Potamia, Analytical Letters 40 (2007) 2203-2216 https://doi.org/10.1080/00032710701567022. 
[10] S. Zhao, H. Yuan, C. Xie, D. Xiao, Journal of Chromatography A 1107 (2006) 290-293 https://doi.org/10.1016/i.chroma.2005.11.052.

[11] P. Nagaraja, R. A. Vasantha, H. S. Yathirajan, Analytical Biochemistry 307 (2002) 316-321 https://doi.org/10.1016/S0003-2697(02)00038-6.

[12] Z. Song, L. Wang, Phytochemical Analysis 14 (2003) 216-220 https://doi.org/10.1002/pca.704.

[13] M. J. Akhtar, M. A. Khan, I. Ahmad, Journal of Pharmaceutical and Biomedical Analysis 16 (1997) 9599 https://doi.org/10.1016/S0731-7085(96)02028-6.

[14] S. Han, X. Chen, Spectrochimica Acta Part A: Molecular and Biomolecular Spectroscopy 210 (2019) 315-320. https://doi.org/10.1016/j.saa.2018.11.051

[15] S. E. Baghbamidi, H. Beitollahi, S. Z. Mohammadi, S. Soltani-Nejad, V. Soltani-Nejad, Chinese Journal of Catalysis 34 (2013) 1869-1875 https://doi.org/10.1016/S1872-2067(12)60655-X.

[16] J. Ghodsi, A. A. Rafati, Y. Shoja, Advanced Journal of Chemistry, Section A 1 (2018) 39-55 http://dx.doi.org/10.29088/sami/AJCA.2018.5.3955.

[17] G. C. Han, X. Su, J. Hou, A. Ferranco, X. Z. Feng, R. Zeng, H. B. Kraatz, Sensors and Actuators B: Chemical 282 (2019) 130-136 https://doi.org/10.1016/i.snb.2018.11.042.

[18] H. M. Moghaddam, H. Beitollahi, S. Tajik, M. Malakootian, H. K. Maleh, Environmental Monitoring and Assessment 186 (2014) 7431-7441 https://doi.org/10.1007/s10661-014-3938-8.

[19] R. Devi, S. Gogoi, S. Barua, H. S. Dutta, M. Bordoloi, R. Khan, Food Chemistry 276 (2019) 350-357 https://doi.org/10.1016/i.foodchem.2018.10.024.

[20] M. M. Foroughi, H. Beitollahi, S. Tajik, A. Akbari, R. Hosseinzadeh, International Journal of Electrochemical Science 9 (2014) 8407-8421

[21] A. A. Kumar, B. K. Swamy, T. S. Rani, P. S. Ganesh, Y. P. Raj, Materials Science and Engineering: C 98 (2019) 746-752 https://doi.org/10.1016/i.msec.2018.12.055.

[22] K. V. Harisha, B. K. Swamy, P. S. Ganesh, H. Jayadevappa, Journal of Electroanalytical Chemistry 832 (2019) 486-492 https://doi.org/10.1016/i.jelechem.2018.11.024.

[23] L. Z. Pei, T. Wei, N. Lin, H. Zhang, C. G. Fan, Russian Journal of Electrochemistry 54 (2018) 84-91 https://doi.org/10.1134/S102319351711012X.

[24] A. Taherkhani, T. Jamali, H. Hadadzadeh, H. Karimi-Maleh, H. Beitollahi, M. Taghavi, F. Karimi, lonics 20 (2014) 421-429 https://doi.org/10.1007/s11581-013-0992-0.

[25] A. O. Idris, J. P. Mafa, N. Mabuba, O. A. Arotiba, Russian Journal of Electrochemistry 53 (2017) 170177 https://doi.org/10.1134/S1023193517020082.

[26] W. H. Elobeid, A. A. Elbashir, Progress in Chemical and Biochemical Research 2 (2019) 24-33 https://doi.org/10.33945/SAMI/PCBR.2019.2.2433.

[27] M. M. Shahid, P. Rameshkumar, A. Numan, S. Shahabuddin, M. Alizadeh, P. S. Khiew, W. S. Chiu, Materials Science and Engineering C 100 (2019) 388-395 https://doi.org/10.1016/j.msec.2019.02.107.

[28] H. Beitollahi, M. Mazloum-Ardakani, B. Ganjipour, H. Naeimi, Biosensors and Bioelectronics 24 (2008) 362-368 https://doi.org/10.1016/j.bios.2008.04.009.

[29] H. Xu, Z. Bai, G. Wang, K. P. O’Halloran, L. Tan, H. Pang, H. Ma, Microchimica Acta 184 (2017) 42954303 https://doi.org/10.1007/s00604-017-2447-1.

[30] H. Beitollahi, S.Tajik, M. R. Aflatoonian, A. Makarem, Analytical and Bioanalytical Electrochemistry 10 (2018) 1399-1413.

[31] V. Mani, M. Govindasamy, S.-M. Chen, B. Subramani, A. Sathiyan, J. P. Merlin, International Journal of Electrochemical Science 12 (2017) 258-267 https://doi.org/10.20964/2017.01.35.

[32] H. Mahmoudi-Moghaddam, S. Tajik, H. Beitollahi, Food Chemistry 286 (2019) 191-196 https://doi.org/10.1016/i.foodchem.2019.01.143.

[33] S. Rana, S. K. Mittal, N. Singh, J. Singh, C. E. Banks, Sensors and Actuators B: Chemical 239 (2017) 1727 https://doi.org/10.1016/i.snb.2016.07.133.

[34] S. Tajik, H. Mahmoudi-Moghaddam, H. Beitollahi, Journal of the Electrochemical Society 166(6) (2019) B402-B406 https://doi.org/10.1149/2.0491906jes.

[35] S. Tajik, M. Safaei, H. Beitollahi, Measurement 143 (2019) 51-57 https://doi.org/10.1016/i.measurement.2019.04.057.

[36] G. Ibáñez-Redín, D. Wilson, D. Gonçalves, O. N. Oliveira Jr., Journal of Colloid and Interface Science 515 (2018) 101-108 https://doi.org/10.1016/j.jcis.2017.12.085. 
[37] H. Beitollahi, M. Mazloum Ardakani, H. Naeimi, B. Ganjipour, Journal of Solid State Electrochemistry 13 (2009) 353-363 https://doi.org/10.1007/s10008-008-0553-z.

[38] M. Haque, Asian Journal of Nanosciences and Materials 2 (2019) 131-148 https://dx.doi.org/10.26655/ajnanomat.2019.3.2.

[39] P. M. Nia, F. Lorestani, W. P. Meng, Y. Alias, Applied Surface Science 332 (2015) 648-656 https://doi.org/10.1016/j.apsusc.2015.01.189.

[40] H. Ekram, N. F. Atta, A. Galal, N. A. Eid, International Journal of Electrochemical Science 13 (2018) 1452-1471 https://doi.org/10.20964/2018.02.30.

[41] H. Beitollahi, S. Tajik, M. H. Asadi, P. Biparva, Journal of Analytical Science and Technology 5 (2014) 29. https://doi.org/10.1186/s40543-014-0029-y

[42] A. Dehno Khalaji, M. Ghorbani, M. Dusek, V. Eigner, Chemical Methodologies 4 (2020) 143-151 https://doi.org/10.33945/SAMI/CHEMM.2020.2.4.

[43] M. A. Khalilzadeh, S. Tajik, H. Beitollahi, R. A. Venditti, Industrial and Engineering Chemistry Research 59 (2020) 4219-4228 https://doi.org/10.1021/acs.iecr.9b06214.

[44] N. Kumar, R. N. Goyal, Sensors and Actuators B: Chemical 239 (2017) 1060-1068 https://doi.org/10.1016/i.snb.2016.08.122.

[45] W. Abdussalam-Mohammed, Journal of Chemical Reviews 1 (2019) 243-251 http://dx.doi.org/10.33945/SAMI/JCR.2019.3.5.

[46] S. Tajik, M.A. Taher, Microchimica Acta 173 (2011) 249-257 https://doi.org/10.1007/s00604-011-0553-z.

[47] M. Mazloum-Ardakani, H. Beitollahi, M. K. Amini, B.-F. Mirjalili, F. Mirkhalaf, Journal of Electroanalytical Chemistry 651 (2011) 243-249 https://doi.org/10.1016/i.jelechem.2010.09.020.

[48] A. Komariah, R. A. Tatara, D. A. Bustami, International Journal of Advanced Biological and Biomedical Research (IJABBR) 5 (2017) 41-47 http://dx.doi.org/10.26655/ijabbr.2017.1.6.

[49] M. R. Ganjali, H. Salimi, S. Tajik, M. Rezapour, B. Larijani, International Journal of Electrochemical Science 12 (2017) 5243-5253 http://dx.doi.org/10.20964/2017.06.88.

[50] P. Norouzi, H. Haji-Hashemi, B. Larijani, M. Aghazadeh, E. Pourbasheer, M. R. Ganjali, Current Analytical Chemistry 13 (2017) 70-80 http://dx.doi.org/10.2174/1573411012666160601150841.

[51] H. Beitollahi, I. Sheikhshoaie, Materials Science and Engineering: C 32 (2012) 375-380 https://doi.org110.1016/j.msec.2011.11.009.

[52] J. Zhang, J. M. Song, H. L. Niu, C. J. Mao, S. Y. Zhang, Y. H. Shen, Sensors and Actuators B: Chemical 221 (2015) 55-62 https://doi.org/10.1016/j.snb.2015.06.040.

[53] G. Fan, Z. Gu, L. Yang, F. Li, Chemical Engineering Journal 155 (2009) 534-541 https://doi.org/10.1016/i.cej.2009.08.008.

[54] B. Mohammadi, L. Salmani, Asian Journal of Green Chemistry 2 (2018) 51-58 https://dx.doi.org/10.22631/ajgc.2017.101962.1033.

[55] K. Kombaiah, J. J. Vijaya, L. J. Kennedy, M. Bououdina, Ceramics International 42 (2016) 2741-2749 https://doi.org/10.1016/i.ceramint.2015.11.003.

[56] P. Zhang, I. Lo, D. O'Connor, S. Pehkonen, H. Cheng, D. Hou, Journal of Colloid and Interface Science 508 (2017) 39-48 https://doi.org/10.1016/i.jcis.2017.08.025.

[57] M. R. Aflatoonian, S. Tajik, M. S. Ekrami-Kakhki, B. Aflatoonian, H. Beitollahi, Eurasian Chemical Communications 2 (2020) 609-618 https://doi.org/10.33945/SAMI/ECC.2020.5.7.

(C)2021 by the authors; licensee IAPC, Zagreb, Croatia. This article is an open-access article distributed under the terms and conditions of the Creative Commons Attribution license (https://creativecommons.org/licenses/by/4.0/) 